\title{
Designing Smart Energy System for Smart City through Municipal Solid Waste to Electricity: Techno-Economic Analysis
}

\author{
Desti Octavianthy ${ }^{1}$, Widodo Wahyu Purwanto ${ }^{1 *}$ \\ ${ }^{1}$ Department of Chemical Engineering, Kampus UI Depok 16424, Depok, Indonesia
}

\begin{abstract}
Smart energy system is one of the important infrastructures for building smart city. Waste to energy (WtE) is an innovative solution using municipal solid waste (MSW) as a source for electricity. This research was conducted to design WtE Plant in Depok and to asses economic viability of different business models. The technologies applied in WtE are anaerobic digestion and gas engine to generate electricity. The simulation was conducted using SuperPro Designer and UniSim Design software to evaluate the technical performances of electricity production from organic solid waste. The feasibility of project implementation of various business models are evaluated through economic analysis. The result of this study shows that the organic fraction of municipal solid waste in Depok has potential to generate electricity up to $28 \mathrm{MW}$. From economic aspect, pay off business scheme greatly affects the value of NPV and IRR. Meanwhile, the intervention scheme on fiscal incentives and low loan interest rate have slight effect on IRR values. A combination of Viability Gap Fund (VGF) and increased tipping fees intervention scheme is an optimum business scheme to build WtE plant and achieve electricity price below the offtaker's willingness-to-pay.
\end{abstract}

\section{Introduction}

Smart city is a sustainable and efficient urban concept that can provide a high quality of life for residents through optimal resource management by utilization of new technologies to transform the urban existing systems, operations and services through participatory of governance. One of the most important infrastructures in the smart city development is energy sector due to the public utility services for urban society. Therefore, the implementation smart energy system through waste to energy (WtE) in smart city is needed to fulfill energy demand for the city in sustainable way using waste produced from urban activities.

Energy demand in Indonesia continues to increase in line with economic growth and population [1]. Power generation in Indonesia is still dominated by fossil fuels, which is about $80 \%$. Renewable energy plays a smaller role, which is about $15 \%$. The most renewable based power generation consists of hydropower and geothermal power plants, each comprising $10 \%$ and $5 \%$ installed in Indonesia [2]. The high use of fossil fuels for electricity generation can lead to increased GHG emissions.

Therefore, WtE are needed to mitigate its negative effects on the environment, especially $\mathrm{CO}_{2}$ emissions. In addition, another crucial issue is high production of municipal solid waste in some urban areas. WtE can also reduce waste problem. Waste which generated in urban area can be utilized as an energy source to generate electricity.

Currently, there are some studies on smart energy system in smart city. Various methods of development for smart energy system have been widely applied in cities in developed and developing countries, such as the cities of Barcelona, Seoul, and Hanoi.

In Stephan Meier's work [3] is discussed the development of smart energy system through the utilization of solar thermal and photovoltaic for building in Austria. Furthermore, there is a study on waste to energy through incineration technology in Macau [4]. Meanwhile, smart energy systems for transportation sectors are applied to Barcelona and Seoul [5]. This study adapts WtE in Hanoi, Vietnam where urban waste can be converted to electricity up to $6.85 \mathrm{GWh} /$ year [6]. However, there has been no study on economic evaluation of $\mathrm{WtE}$, especially for project funding schemes.

Rapid economic growth in Indonesia has created a significant increase consumption level, which leads to an increased number of municipal waste generations per capita. With 1.7 million inhabitants with population growth of $4 \%$, waste generation rate will increase steadily as the economic growth continues in Depok [7].

*Corresponding author: widodo@che.ui.ac.id 
Depok is a city in West Java which produced high amount of waste generation up to $766 \mathrm{~m}^{3}$ or 766,000 litres of waste per day [8]. Household is most contributed for organic solid waste produced for about $54 \%$ of total waste production [9]. Currently, Depok has Cipayung landfill as the final waste dumping place where waste has not been able to be utilized optimally. Hence, WtE technology with an appropriate project funding scheme as an alternative solution.

The objective of this study is to analyze technical performance of a smart energy system via WtE through conversion of municipal solid waste into electricity by anaerobic digestion and gas engine power plant. This study is also to find an appropriate business scheme to achieve electricity price below offtaker's willingness-topay.

\section{Method}

\subsection{Process Description and Performances}

\subsubsection{Anaerobic Digestion}

Anaerobic digestion is a $\mathrm{WtE}$ technology that involves a biochemical process in which organic waste will decompose by anaerobic microorganisms in the absence of dissolved oxygen (anaerobic condition) [10]. Anaerobic microorganisms digest organic material which is converted through anaerobic degradation to a more stable form resulting in a high energy biogas which main composition consists of methane $\left(\mathrm{CH}_{4}\right)$ and carbon dioxide $\left(\mathrm{CO}_{2}\right)$. There are several key parameters that must be maintained during digestion process in digester. Table 1 shows key parameters of digester.

Table 1. Key Parameter of Digester

\begin{tabular}{|l|c|}
\hline \multicolumn{1}{|c|}{ Key Parameter } & Operating Condition \\
\hline $\begin{array}{l}\text { Temperature (mesophilic, } \\
{ }^{\circ} \mathrm{C} \text { ) }\end{array}$ & 40 \\
\hline C/N ratio & 25 \\
\hline Pressure input, bar & 1 \\
\hline $\begin{array}{l}\text { Hydraulic retention time, } \\
\text { days }\end{array}$ & 30 \\
\hline
\end{tabular}

Kinetic reaction of biogas production uses Monod model [11].

$$
r=-\mu\left(\frac{X}{Y}\right)
$$

Where $r$ represents the rate of reaction, $X$ is the total biomass, $\mathrm{Y}$ is the yield, and $\mu$ is the bacterial growth rate defined as:

$$
\mu=-\mu_{m}\left(\frac{s}{K+s}\right)
$$

Where $\mathrm{S}$ is the substrate concentration and $\mathrm{k}$ is the rate constant. The rate constant is defined as:

$$
k=0.8+0.0016 x e^{0.06 x s}
$$

This equation may apply to the reaction of digestion in the temperature range $20^{\circ} \mathrm{C}$ to $60^{\circ} \mathrm{C}$ in order to apply the value of $\mu m$ :

$$
\mu_{m}=0,013 T-0,129
$$

The chemical reaction of food waste conversion to biogas can be described below:

$$
\begin{aligned}
& \mathrm{C}_{6} \mathrm{H}_{9.6} \mathrm{O}_{3.5} \mathrm{~N}_{0.28} \mathrm{~S}_{0.2}+1.95 \mathrm{H}_{2} \mathrm{O} \rightarrow 3.275 \mathrm{CH}_{4}+2.725 \\
& \mathrm{CO}_{2}+0.2 \mathrm{H}_{2} \mathrm{~S}+0.14 \mathrm{~N}_{2}
\end{aligned}
$$

\subsubsection{Biogas Treatment}

The gas formed from the digestion process as raw biogas is processed into the chemical solvent absorber to remove $\mathrm{H}_{2} \mathrm{~S}$ and reduce $\mathrm{CO}_{2}$ content to prevent mechanical corrosion before it flows to the gas engine unit. Solvent used for sweetening biogas is methyldiethanolamine (MDEA). Tertiary amine, such as MDEA exhibit a selectivity for $\mathrm{H}_{2} \mathrm{~S}$ over $\mathrm{CO}_{2}$ when contacting gas streams containing both acid gases [12]. MDEA is then regenerated in desorber column. $\mathrm{H}_{2} \mathrm{~S}$ removal efficiency can define as:

$$
\begin{aligned}
& \eta \mathrm{H}_{2} \text { S removal }=\frac{\text { \$bmole } \mathrm{H}_{2} \mathrm{~S} \text { in sweet biogas }}{\text { \%hole } \mathrm{H}_{2} \mathrm{~S} \text { in biogas }} \\
& \mathrm{H}_{2} \text { S removed } / \mathrm{kJ}=\frac{\mathrm{H}_{2} \text { S removed }(\mathrm{kmol})}{Q(\mathrm{~kJ})}
\end{aligned}
$$

\subsubsection{Gas Engine Power Generation}

Gas engine is an internal combustion engine which runs on a gas fuel, such as biogas and natural gas. Gas engine has thermodynamic principle, namely Otto cycle. Compression ratio in gas engine is $1: 9.5$ to $1: 11$ [13]. Equivalence ratio air-fuel can be described as:

$$
\emptyset=\frac{\text { AFRS }}{\text { AFR actual }}
$$

Where $\varnothing$ is equivalent air-fuel ratio and AFRS is air-fuel ratio stoichiometry. Adiabatic flame temperature from combustion for biogas is $1872^{\circ} \mathrm{C}$. Thermal efficiency from combustion process is defined as:

$$
\eta_{\mathrm{th}}=\left(1-\frac{1}{\gamma^{k-1}}\right)
$$

where $k$ is heat capacity ratio. Meanwhile, electrical efficiency of the cycle can be formulated as:

$$
\eta_{\text {el }}=\frac{\text { Wnet }}{\text { Qin }}=\frac{3600}{L H V x \frac{Q g a s}{W}}
$$

\subsection{Process Simulation}

\subsubsection{Production and Treatment of Biogas}


A mass and energy balance model of the anaerobic digestion system simulated by SuperPro Designer software. Figure 1 shows process flow diagram of biogas

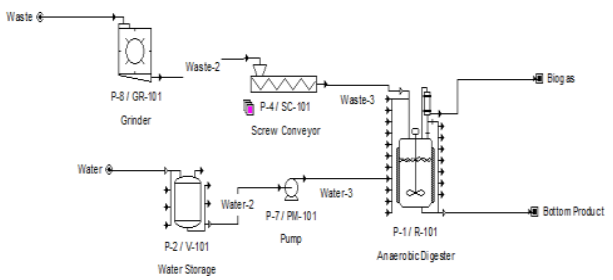

production.

Fig.1. Process Flow Diagram of Biogas Production

Due to biogas properties that hydrogen sulphide content must be less than $5 \mathrm{ppm}$ flows to the gas engine, then the biogas is sweetened using chemical solvent absorption. Biogas sweetening simulation was done by using UniSim Design software. Process flow diagram of biogas sweetening process is described on Figure 2.

Sweet biogas is then mixed with air before it flows to gas engine for combustion. Gas engine power plant simulation was done by using UniSim Design software. Air-fuel ratio in gas engine is $1: 11$, while the input pressure of biogas to gas engine is 2 bars. Meanwhile, compression ratio in gas engine reaches 1:11.

\subsubsection{Model Description and Assumption}

Input waste is assumed to have been segregated so that only the organic waste fraction is inputted into the simulation. Before organic waste is fed into digester, its size is reduced to $0.2 \mathrm{~mm}$ by grinder in order to maximize biogas produced. Organic waste is fed into anaerobic digester using screw conveyor and water is pumped into anaerobic digester with ratio waste and water 1:1.95 respectively. The amount of waste inputted into the system is set at $414 \mathrm{~m}^{3}$. It requires 30 digesters to convert waste into biogas continuously with each volume of digester is about $1,822 \mathrm{~m}^{3}$.

In order to remove hydrogen sulphide content in biogas, sweetening process by using absorption technology is required. Biogas which generated from biodigester flows into the absorber package which consists of absorber, desorber, also involves some equipment's, such as heat exchanger, valve and pump to regenerate MDEA as a solvent. Biogas flows through compression and combustion process in gas engine power plant. Figure 2 describes process flow diagram of WtE.

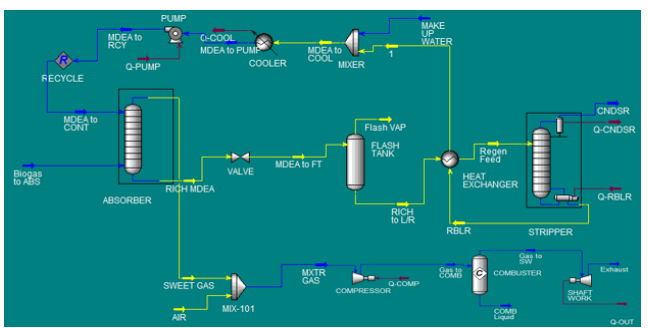

Fig.2. Process Flow Diagram of WtE

\subsection{Economic Analysis}

Some scenarios of business models and project financing are identified based on existing regulation on WtE plant in Indonesia and some fiscal and financial incentives. The scenarios as input for economic feasibility analysis through economic feasibility parameters, such as NPV, IRR, and PBP to find out workable business scheme. Table 2 provides some scenarios of business models and financing schemes of WtE.

Table 2. Scenarios of Business Model

\begin{tabular}{|c|c|c|}
\hline Name & $\begin{array}{c}\text { Business } \\
\text { Model }\end{array}$ & Detail Scenario \\
\hline BMB & Base Case & $\begin{array}{l}\text { - Loan interest rate: } \\
6.5 \% \\
\text { - } \text { Income tax: } 25 \% \\
\text { - Exemption of import } \\
\text { duty } \\
\text { - Electricity price : Rp } \\
\text { 910/kWh }(6.5 \\
\text { cent/kWh) - MEMR } \\
\text { No. } 1404 \mathrm{~K} / 2017 \\
\text { Tipping fee : US } \$ \\
\text { 10/ton of waste } \\
\end{array}$ \\
\hline BMFI-1 & $\begin{array}{c}\text { Fiscal } \\
\text { Incentives-1 }\end{array}$ & $\begin{array}{l}\text { Income tax rate } \\
\text { exemption }\end{array}$ \\
\hline BMFI-2 & $\begin{array}{c}\text { Fiscal } \\
\text { Incentives-2 }\end{array}$ & $\begin{array}{l}30 \% \text { net income } \\
\text { deduction is charged for } \\
\text { each } 6 \text { years at } 5 \% \text { per } \\
\text { annum - MOF No. } 21 \\
/ 2010\end{array}$ \\
\hline BMLI & $\begin{array}{l}\text { Low Loan } \\
\text { Interest }\end{array}$ & $\begin{array}{l}\text { Low loan interest from } \\
\text { International support : } \\
3 \%\end{array}$ \\
\hline BMVGF & $\begin{array}{l}\text { Viability Gap } \\
\text { Fund }\end{array}$ & $\begin{array}{l}50 \% \text { of capital } \\
\text { investment from } \\
\text { government - MOF } \\
\text { No.223/PMK.011/2012) }\end{array}$ \\
\hline BMTF & $\begin{array}{l}\text { Increased } \\
\text { Tipping Fee }\end{array}$ & $\begin{array}{l}\text { Increased revenue from } \\
\text { tipping fee : US\$ 50/ton } \\
\text { of waste }\end{array}$ \\
\hline $\mathrm{BMG}$ & Grant & $\begin{array}{l}100 \% \text { grant of capital } \\
\text { investment from } \\
\text { International support }\end{array}$ \\
\hline BMP & $\begin{array}{l}\text { Electricity } \\
\text { pricing }\end{array}$ & $\begin{array}{l}\text { Electricity price : } \\
\$ 0.14 / \mathrm{kWh} \text { - Presidential } \\
\text { Decree No.4/2016 }\end{array}$ \\
\hline $\begin{array}{l}\text { BMP \& } \\
\text { BMLI }\end{array}$ & $\begin{array}{l}\text { Combined } \\
\text { BMP and } \\
\text { BMLI }\end{array}$ & $\begin{array}{l}\text { Electricity price : } \\
\$ 0.14 / \mathrm{kWh}- \\
\text { Presidential Decree } \\
\text { No.4/2016 } \\
\text { Low loan interest : } \\
3 \%\end{array}$ \\
\hline $\begin{array}{l}\text { BMP, } \\
\text { BMVGF, } \\
\text { BMTF }\end{array}$ & $\begin{array}{l}\text { Combined } \\
\text { BMP, } \\
\text { BMVGF, and } \\
\text { BMTF }\end{array}$ & $\begin{array}{l}\text { Electricity price : } \\
\$ 0.14 / \mathrm{kWh}- \\
\text { Presidential Decree } \\
\text { No.4/2016 } \\
\text { - } 50 \% \text { grant of capital }\end{array}$ \\
\hline
\end{tabular}




\begin{tabular}{|c|c|c|}
\hline & & $\begin{array}{l}\text { investment from } \\
\text { government - MOF } \\
\text { No.223/PMK.011/20 } \\
12 \\
\text { - Increased revenue } \\
\text { from tipping fee : } \\
\text { US\$ 50/ ton of waste }\end{array}$ \\
\hline $\begin{array}{l}\text { BMVGF, } \\
\text { BMTF, } \\
\text { BMFI-1 }\end{array}$ & $\begin{array}{c}\text { Combined } \\
\text { BMVGF, } \\
\text { BMTF, and } \\
\text { BMFI-1 }\end{array}$ & $\begin{array}{ll}\text { - } & 50 \% \text { grant of capital } \\
\text { investment from } \\
\text { government - MOF } \\
\text { No.223/PMK.011/20 } \\
12 \\
\text { - Increased revenue } \\
\text { from tipping fee : } \\
\text { US\$ 50/ton of waste } \\
\text { - Exemption of income } \\
\text { tax rate }\end{array}$ \\
\hline
\end{tabular}

\section{Result and Discussion}

\subsection{Technical Performance}

\subsubsection{Biogas Production and Treatment}

According to the simulation result, the composition of biogas consist of $56.68 \%$ mole of methane, $30.05 \%$ mole of $\mathrm{CO}_{2}, 11.56 \%$ mole of $\mathrm{N}_{2}$, and $1.71 \%$ mole of $\mathrm{H}_{2} \mathrm{~S}$. The organic waste in Depok has potential to produce methane about $99,837 \mathrm{sm}^{3} /$ day and generate biogas for about $176,142 \mathrm{sm}^{3} /$ day. A ton of organic waste can generate biogas up to $425.5 \mathrm{sm}^{3}$. Lower heating value of biogas generated is about $17.8 \mathrm{MJ} / \mathrm{kg}$.

The composition of biogas before and after sweetening process is described in Table 3.

Table 3. Composition of Biogas Before and After Sweetening

\begin{tabular}{|c|c|c|}
\hline Component & $\begin{array}{c}\text { Composition of } \\
\text { Feed Biogas } \\
\text { (\% mole) }\end{array}$ & $\begin{array}{c}\text { Composition of } \\
\text { Biogas Treated } \\
\text { (\% mole) }\end{array}$ \\
\hline $\mathrm{CH}_{4}$ & 56.7 & 63 \\
\hline $\mathrm{CO}_{2}$ & 30 & 25 \\
\hline $\mathrm{H}_{2} \mathrm{~S}$ & 1.7 & 0.0001 \\
\hline $\mathrm{N}_{2}$ & 11.6 & 12 \\
\hline
\end{tabular}

The composition of $\mathrm{H}_{2} \mathrm{~S}$ in treated biogas becomes $0.48 \mathrm{ppm}$ or equivalent to $0.0001 \%$ mole. This indicates that biogas is feasible and meets the requirements as a fuel for gas engine. $\mathrm{H}_{2} \mathrm{~S}$ removal efficiency reaches $99.9 \%$ while $\mathrm{CO}_{2}$ removal efficiency is about $17 \%$ (as $\mathrm{CO}_{2}$ is not main constraint to be removed). It requires 6.4 mole of MDEA to remove 1 mole $\mathrm{H}_{2} \mathrm{~S}$ content. According to the Equation (8), in order to removing $\mathrm{H}_{2} \mathrm{~S}$ content and decrease $\mathrm{CO}_{2}$ content in biogas, it requires electrical energy about $2.57 \mathrm{~kW}$ and thermal energy about 130,126 MJ/h.

\subsubsection{Power Generation}

Adiabatic flame temperature that produced from combustion process is $1870^{\circ} \mathrm{C}$, while thermal efficiency obtained is $45 \%$. Biogas produced from organic waste in Depok has potential to generate electricity up to $28 \mathrm{MW}$ with capacity factor of 0.7 . Heat rate which obtained from simulation result is $10,384 \mathrm{~kJ} / \mathrm{kWh}$. This power plant requires total electricity for compressor, pump, grinder, and conveyor for about $18 \mathrm{MW}$. Therefore, total electricity that can be sold to offtaker is about $10 \mathrm{MW}$. Electrical efficiency of power plant is $35 \%$.

Figure 4 is a summary of the quantity of flow in the form of efficiency ranging from waste into electricity that is illustrated through the Sankey Diagram.

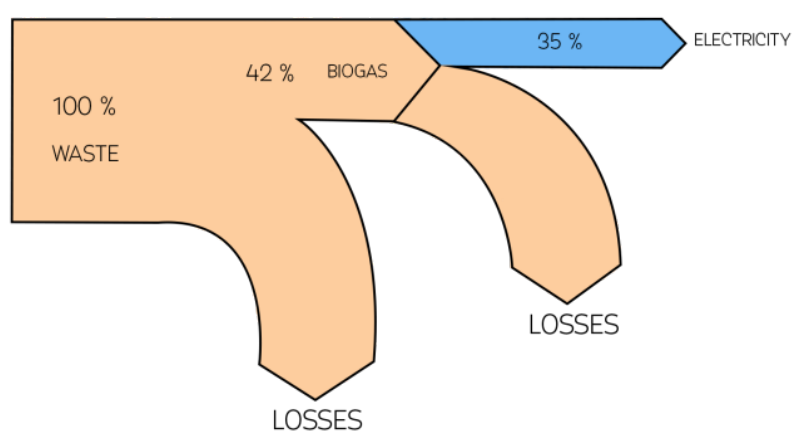

Fig.3. Sankey Diagram

Losses from waste conversion to biogas is in the form of sludge, while losses from biogas conversio to electricity is in the form of heat waste.

\subsection{Economic Performance}

\subsubsection{Investment Cost}

Investment cost of WtE consists of total direct cost and indirect cost. Total direct cost includes equipment cost, land and building cost, service facilities, piping and instrumentation. Total indirect cost includes construction expenses, contactors fee, engineering and supervision, also contingency. Total Capital Investment of WtE is about US\$ 119,917,901. Total investment cost of WtE reaches US\$ 4,158/kW. This result is fits within the investment cost range based on IRENA [14].

\subsubsection{Operating Cost}

Operating cost of waste to energy plant consists of variable cost and fixed cost. Variable cost includes labor cost, utility cost, and waste logistic cost. Fixed cost includes insurance, tax, and distribution cost. Total operating cost of WtE is about US\$ 3,669,481/year which corresponding to $3 \%$ of Total Capital Investment Cost. 


\subsubsection{Biogas Production and Treatment Cost}

Total biogas production cost includes investment cost and operating \& maintenance cost. Due to biogas is from waste, so there is no fuel cost in biogas production cost breakdown. Total production cost of biogas reaches US\$ $0.12 / \mathrm{m}^{3}$ methane.

\subsubsection{Electricity Production Cost}

Total annual cost of electricity production is US\$ 9.547.349/year while annual electricity produced is 63.360.000 kWh/year. Cost of electricity production reaches US\$ 0.15/kWh.

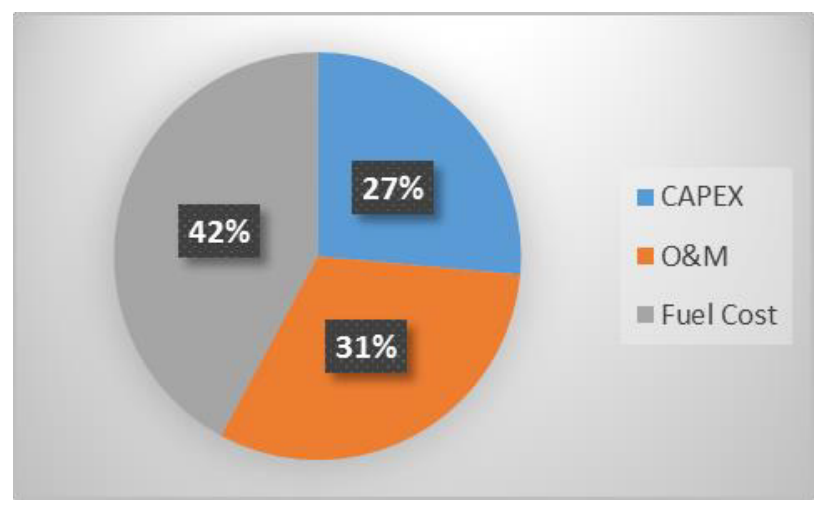

Fig.4. Electricity Production Cost

\subsubsection{Optimum Business Model}

Electricity tariff from WtE is about $\mathrm{Rp} 3,579 / \mathrm{kWh}$. Meanwhile, the government has regulated feed in tariff (FiT) in accordance with Presidential Decree No.4/2016 for electricity selling price of WtE worth Rp 1,800/kWh in West Java. This makes FiT so unattractive. Therefore, a change on FiT is required. Some intervention schemes on CAPEX, financial, and fiscal incentives are also required if there are no changes on FiT. Some scenarios of business models/interventions that described on Table 4 are evaluated by economical parameters.

Table 4. Intervention Scheme Results

\begin{tabular}{|c|c|c|c|c|}
\hline Name & NPV & $\begin{array}{c}\text { IRR } \\
\mathbf{( \% )}\end{array}$ & $\begin{array}{c}\text { PBP } \\
\text { (year) }\end{array}$ & $\begin{array}{c}\text { Electricity } \\
\text { tariff } \\
\text { (Rp/kWh) }\end{array}$ \\
\hline BMB & $-115,295,113$ & - & - & 3,579 \\
\hline BMFI-1 & $-99,242,823$ & - & - & 3,356 \\
\hline BMFI-2 & $-106,107,364$ & - & - & 3,390 \\
\hline BMLI & $-98,731,113$ & - & - & 3,120 \\
\hline
\end{tabular}

\begin{tabular}{|c|c|c|c|c|}
\hline $\begin{array}{c}\text { BMVG } \\
\text { F }\end{array}$ & $-43,738,125$ & - & - & 2,086 \\
\hline BMTF & $-54,349,779$ & - & - & 2,372 \\
\hline BMG & $90,861,730$ & 29.6 & 5 & 703 \\
\hline BMP & $-73,004,564$ & - & - & 3,085 \\
\hline $\begin{array}{c}\text { BMP \& } \\
\text { BMLI }\end{array}$ & $-65,410,384$ & - & - & 2,820 \\
\hline $\begin{array}{c}\text { BMP, } \\
\text { BMVG } \\
\text { F \& } \\
\text { BMTF }\end{array}$ & $34,987,358$ & 14.6 & 7 & 1,273 \\
\hline $\begin{array}{c}\text { BMVG } \\
\text { F, } \\
\text { BMTF } \\
\&\end{array}$ \\
\begin{tabular}{c} 
BMFI-1 \\
\hline
\end{tabular} & $1,154,919$ & 8.3 & 10 & 1,423 \\
\hline
\end{tabular}

The results show that pay off business scheme greatly affects the value of NPV and IRR. Meanwhile, the intervention scheme on fiscal incentives and low loan interest rate have slight effect on IRR values.

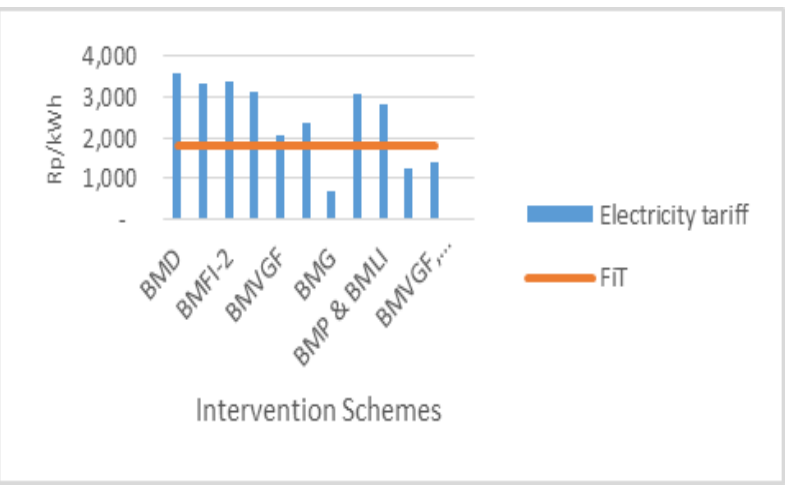

Fig.5. Electricity Tariff

Based on calculation, a proper funding scheme to achieve the willingness-to-pay offtaker is the BMG funding scheme, a combination of SPP funding scheme, SPVGF \& SPTF, and a combination of SPVGF, SPTF \& SPFI-1 funding schemes in which these three business models has IRR greater than MARR (8\%). From all of the intervention schemes, the best business model for WtE is a combination of SPP, SPVGF \& SPTF funding scheme. This business model has IRR for about $14.6 \%$ and obtained electricity price for about Rp 1,273/kWh. Payback period obtained is 7 year which means that this business model is optimum and feasible to build WtE. 


\subsection{Environmental Analysis}

WtE processing also generates $\mathrm{CO}_{2}$ emission. From the simulation results, $\mathrm{CO}_{2}$ intensity that produced from WtE plant is about $357 \mathrm{gCO} 2-\mathrm{eq} / \mathrm{kWh}$. Comparation of $\mathrm{CO}_{2}$ intensity from various sources are provided on Figure 6.

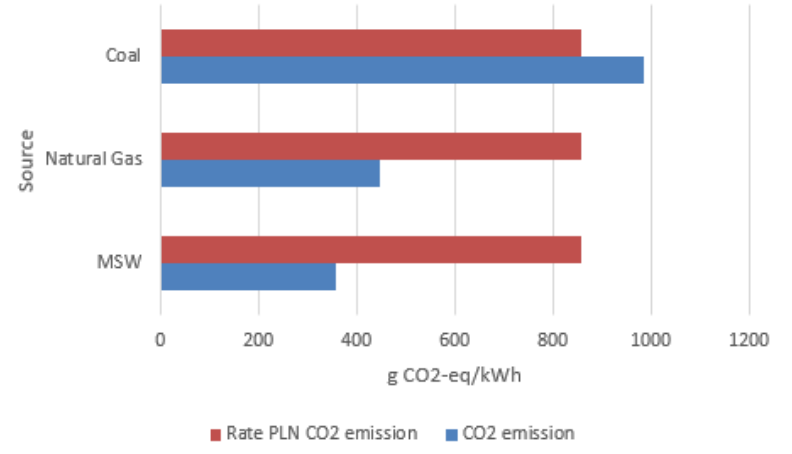

Fig.6. Comparation of $\mathrm{CO}_{2}$ Intensity

According to the results, municipal solid waste (MSW) is more environmental friendly than other sources. The differentiation of $\mathrm{CO}_{2}$ intensity between MSW and rate of PLN reaches $500 \mathrm{gCO}_{2}$-eq $/ \mathrm{kWh}$. This result indicates that production of electricity from waste can reduce $\mathrm{CO}_{2}$ emission up to 31,671 ton $\mathrm{CO}_{2}$-eq/year comparing to $\mathrm{CO}_{2}$ intensity of PLN's rate. Therefore, waste to energy is a promising alternative because it produces less $\mathrm{CO}_{2}$ emission than other sources.

\section{Conclusion}

High production of municipal solid waste in urban areas have been promoted as the big issue due to urbanization. The most common type of waste produced in urban areas is organic waste. Anaerobic digestion is reliable technology to convert waste into energy outright reducing the amount of organic waste drastically. Waste to energy (WtE) is a promising alternative to fulfill energy demand of urban society.

Besides reducing the amount of waste, $\mathrm{WtE}$ generates low $\mathrm{CO}_{2}$ emission so it is environmentally friendly. However, the investment cost of WtE is high so that the cost of electricity production becomes expensive compared to the other energy sources from fossil fuels. Therefore, the funding intervention schemes are analysed to make WtE becomes attractive and feasible to be developed.

\section{Acknowledgement}

The funding of this research/article's publication is supported by the United States Agency for International Development (USAID) through the Sustainable Higher Education Research Alliance (SHERA) Program for Universitas Indonesia's Scientific Modeling, Application, Research and Training for City-Centered Innovation and Technology (SMART CITY)
Project, Grant \#AID-497-A-1600004, Sub Grant \#IE00000078-UI-1 No. 0142/UN2.R3.SC/HKP.05.01/2018.

\section{References}

1. World Bank. Rasio elektrifikasi di Indonesia. The World Bank Group (2013)

2. World Bank. Konsumsi bahan bakar fosil di Indonesia. The World Bank Group (2014)

3. Maier, S. Smart energy systems for smart city districts: case study Reininghaus District. Energy, Sustainability, and Society 6 : 23 (2016)

4. Qingbin, Song., et al. Characterizing the essential materials and energy performance of city buildings: A case study of Macau. Journal of Cleaner Production 194 : 263-276 (2018)

5. Grimaldi, D., Vicenc Fernandez. The alignment of University curricula with the building of a Smart City: A case study from Barcelona. Technological Forecasting \& Social Change 123 : 298-306 (2017)

6. Nguyen, H., Heaven, S. Energy potential from the anaerobic digestion of food waste in municipal solid waste stream of urban areas in Vietnam. International Journal Energy Environment 5 : 365374 (2014)

7. Kristanto, Gabriel Andari., Irma Gusniani., Aristiati Ratna. The performance of municipal solid waste recycling program in Depok, Indonesia. International Journal of Technology 2 : 264-272 (2015)

8. Centre of Environmental Technology, BPPT. Produksi limbah pada kota-kota besar di Indonesia. Final Report: Municipal Solid Waste Technology (2016)

9. United Nations Centre for Regional Development. Data komposisi limbah padat perkotaan di Indonesia. Final Report: Waste Management Technology (2015)

10. Gunaseelan, V.N. Anaerobic digestion of biomass for methane production: A review. Biomass and Bioenergy Journal 6 : 83-144 (2007)

11. Charles, G.Gunerson., David C.Stuckey. Anaerobic digestion principal and practices for biogas system. The World Bank, Washington D.C, USA (1986)

12. Mining, S. Francis., Richard, E. Thompson. Oilfield processing of petroleum volume 1: Natural gas. PennWell Publishing Company (1991)

13. Moran, Michael J., Howard N. Saphiro. Fundamental of engineering thermodynamics $7^{\text {th }}$ edition. John Wiley \& Sons, Inc (2010)

14. IRENA. Investment cost dan fixed O\&M of waste to energy. International Renewable Energy Agency. (2012) 